DE DE GRUYTER

OPEN
Journal of Intercultural Management

Vol. 6, No. 1, January 2014, pp. 17-25

DOI 10.2478/joim-2014-0002

\author{
Alicja Anna Winiarska-Januszewicz \\ Clark University
}

Jacek Winiarski

Uniwersytet Gdański

\title{
Advancing Leadership Pipeline Through the Development of High-Potential Employees
}

At the end of the day, the company with the best team, the best people will win in the long run." (GE)

\begin{abstract}
Per latest research of Corporate Executive Board - Corporate Leadership Council organization (CLC) in HiPo Program Operations and Outcomes Survey, highpotential employees are defined as twice as valuable to an organization and three times more likely to succeed as future leaders. However, the number of high potentials has declined $48 \%$ over last $5-10$ years.

Talent management (TM) represents organization's effort to attract, develop and retain skilled and valuable employees. Its goal is to make sure that organization has all capabilities and commitment needed for current and future organization success. An organization's talent pool, specifically management talent, is often referred to as leadership pipeline.

Leadership pipeline is managed with a help of various systems, processes and organization structure. The pipeline changes as the organization needs change and is influenced by many inside and outside influencers. The goal overall is to make sure that organization can identify who "is ready now" and who is "on track" for larger leaderships roles. Managing this identification and making sure talent pool is aligned with organization needs is in today's economy the greatest challenge for talent management.

Employees within the leadership pipe - mangers and leaders need to be managed with
\end{abstract}


strategy that measures employees' performance and ability along with aspiration and engagement. TM needs to ensure that the criteria used to identify pipeline members are consistently applied across the workforce and clearly communicated with them about their status and associated responsibilities, as they are the pool of future organizational leaders.

Talent management strategy for high potentials often fails as organizations select the wrong criteria to identify leadership pipeline members. Confusing performance with potential, lack of due diligence, vague criteria and questionable accuracy are among many challenges that are present while building organization talent pool.

Key words: Leadership pipeline, Talent management.

\section{DEFINITION OF HIGH POTENTIAL}

Who is a High-Potential Employee?

In a Harvard Business Review article from October 2011, Fernandez-Araoz, Groysberg and Nitin, "How to Hang On to Your High Potentials," define potential as a person's ability to succeed in roles with responsibilities of greater scale and scope. The authors describe "greater scale" as "a job in the same area but with, say, a larger budget or staff." "Greater scope" is "a job involving activities of substantially more breadth and complexity" (pp. 75-83).

In a Business Strategy Review article from March 2010, "The Anatomy of a High Potential," authors Ready, Conger, Hill, and Stecker identify the basic characteristics of a high potential employee as "delivering strong results, credibly and not at others' expense," "mastering expertise beyond the technical," and "behaving in ways consistent with the company's values" (pp. 52-55). The authors then go on to identify additional " $x$-factors" that separate high potentials from a pack of otherwise strong performers. These " $\mathrm{x}$-factors" include a drive to excel, a catalytic learning capability, an enterprising spirit, and dynamic sensors.

Per well known consulting agency AonHewitt in January 2013, report Building the Right Potential Pool, high potential is an individual that demonstrates the intellectual aptitude and leadership capacity to progress through multiple roles of increased responsibility, complexity, and scope and is likely to do so at an accelerated pace possibly taking at least two new roles in five years (p. 4).

Michael Campbell and Roland Smith from Center for Creative Leadership (CCL) in their latest report A View from Inside the Leadership Pipeline are defining high potential as employees who are assessed as having the ability, organizational commitment, and motivation to rise to and succeed in more senior positions in the organization (p. 6).

Bersin by Deloitte member O'Leonard in September 2012, Investing in the Future: High Potentials report defines a high-potential employee as an employee who has been identified as having the potential, ability and aspiration for successive leadership positions within the company (p.4). 
Summarizing in reality different organizations will have their own definitions of high potential talent but the main characteristic will include:

- ability (the combination of innate characteristics and learned skills),

- aspiration (the desire for the responsibilities, challenges, and rewards of more senior roles),

- and engagement (the employee's commitment).

Figure 1: CEB CLC Model of High-Potential Employee

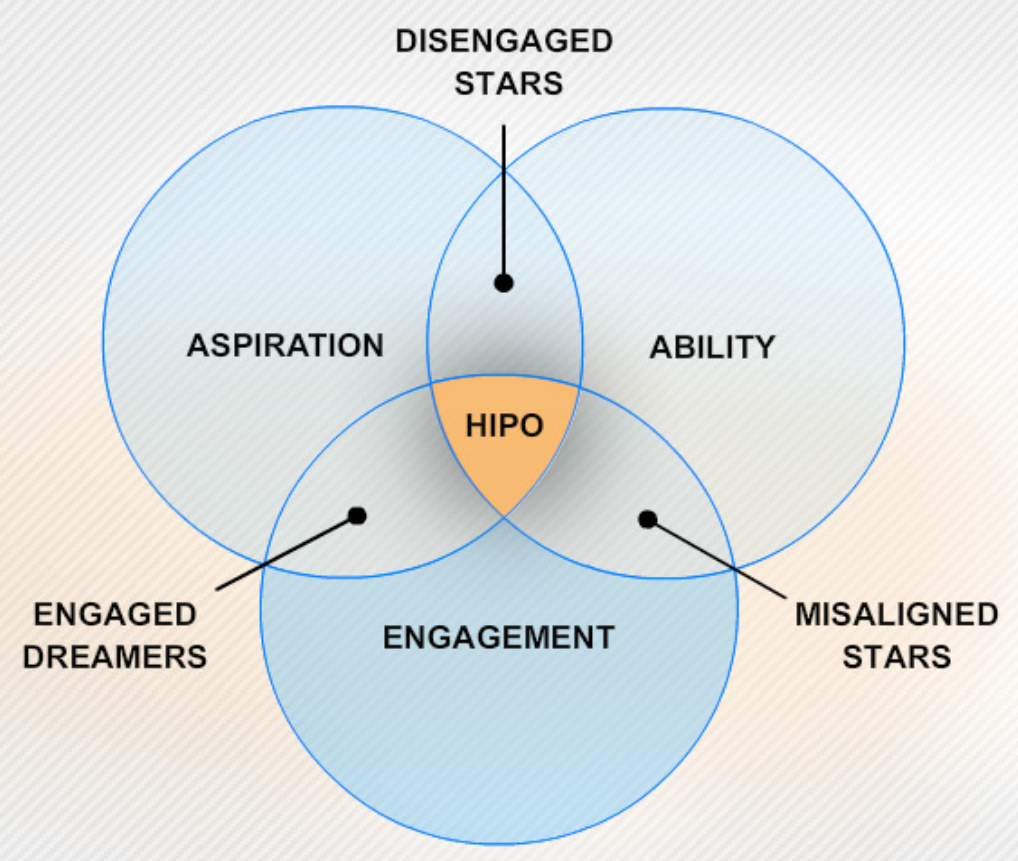

Source: Corporate Executive Board - Corporate Leadership Council, Talent Development - High Potentials

In the model presented above, ability stands for a combination of the innate characteristics and learned skills that enable employees to carry out their day-to-day work. Innate characteristic is mental/cognitive agility and emotional intelligence. Learned skills will include technical/functional skills and interpersonal skills.

Second element of the model - aspiration describes employees with aspiration as those, who desire responsibilities and rewards that come with 
more senior roles. These responsibilities and rewards include: prestige and recognition, advancement and influence, financial rewards, work-life balance, and overall job enjoyment.

Third element of the model is engagement - employees with engagement capital exhibit commitment, discretionary effort, and intent to stay. Their level of engagement capital is based on perceptions of three areas:

- past events with the employer,

- present experiences,

- future expectations of employment experience.

\section{DEVELOPMEMT OF HIGH POTENTIALS}

Because high potential talent is so important to the organization well being development of high potentials should be priority for talent management.

When providing high potentials with the right developmental opportunities and selecting relevant success measures, organizations should be aiming to create a robust high-potential employee program that makes better leaders and accelerates their path to leadership thus advancing the leadership pipeline.

Talent management using multiple methods of assessment and comparing results with known criteria that are associated with specific leadership requirements for organization should establish guidelines for development and mentoring in order to keep high potentials performing on highest level. Systematically defined, by talent management, development areas supported by developmental activities within 70-20-10 rule will support high potentials individual development plans and keep them engaged and moving forward.

The most popular development for high potentials is internal education delivered in a form of the leadership program. In order to accelerate high potentials leadership development program needs to be build within the framework of the 70-20-10 rule and supported by Individual Development Plan.

Figure 2: 70-20-10 Learning Rule

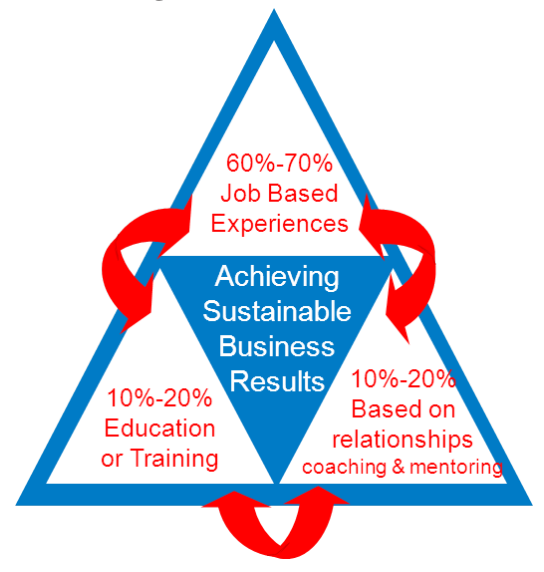


Please refer to the table below for examples of development activities with 70-20-10 rule.

Table 1: Learning Activities with 70-20-10 rule.

\begin{tabular}{|c|c|c|}
\hline \multirow{8}{*}{$\begin{array}{l}\text { Job Based Experi- } \\
\text { ences } \\
70 \%\end{array}$} & Job shadowing & Expatriate assignment \\
\hline & High profile assignments & $\begin{array}{l}\text { Cross-functional assignment / proj- } \\
\text { ect }\end{array}$ \\
\hline & Stretch assignments & Continuous improvement project \\
\hline & $\begin{array}{l}\text { On-the-job training / job en- } \\
\text { largement }\end{array}$ & Volunteering / community service \\
\hline & $\begin{array}{l}\text { Rotations / cross-training / } \\
\text { position swap }\end{array}$ & $\begin{array}{l}\text { Attending or presenting at function- } \\
\text { al reviews, budget reviews, company } \\
\text { meetings }\end{array}$ \\
\hline & Project teams & $\begin{array}{l}\text { Learning from job based hardships } \\
\text { or set-backs }\end{array}$ \\
\hline & Short-term assignments & Teaching others \\
\hline & $\begin{array}{l}\text { Joining a taskforce / commit- } \\
\text { tee }\end{array}$ & $\begin{array}{l}\text { Leadership role in an Employee Re- } \\
\text { source Group }\end{array}$ \\
\hline \multirow{7}{*}{$\begin{array}{l}\text { Leverage Relation- } \\
\text { ships } \\
\text { (Learning from } \\
\text { Self } \\
\text { and Others) } \\
20 \%\end{array}$} & Good managers & Online communities (e.g., Linked In) \\
\hline & Functional advisors / mentors & $\begin{array}{l}\text { Feedback (informal or formal } 360 \\
\text { process) }\end{array}$ \\
\hline & Development or peer coaches & Mentoring other \\
\hline & Professional organizations & External relationships \\
\hline & $\begin{array}{l}\text { Meetings with subject matter } \\
\text { experts or outside experts }\end{array}$ & $\begin{array}{l}\text { Learning from relationship hard- } \\
\text { ships or set-backs }\end{array}$ \\
\hline & $\begin{array}{l}\text { Network - internal or external } \\
\text { (e.g., alumni) }\end{array}$ & Joining an external board \\
\hline & $\begin{array}{l}\text { Presenting at conferences, } \\
\text { outside meetings, boards, } \\
\text { councils }\end{array}$ & $\begin{array}{l}\text { Seeking Sr. Leader as a career cham- } \\
\text { pion or advisor }\end{array}$ \\
\hline \multirow{5}{*}{$\begin{array}{l}\text { Education and } \\
\text { Training } \\
10 \%\end{array}$} & Professional conferences & Books, articles, journals, videos \\
\hline & Self-study & External resources (e.g., associations) \\
\hline & Business simulations & $\begin{array}{l}\text { Internal training and development } \\
\text { courses }\end{array}$ \\
\hline & Professional certifications & $\begin{array}{l}\text { Leadership or technical programs / } \\
\text { forums }\end{array}$ \\
\hline & $\begin{array}{l}\text { Online resources (Wiki/Web } \\
\text { Pages/Blog; Webinars) }\end{array}$ & Formal education \\
\hline
\end{tabular}

Research shows that leveraging experiential activities is the most powerful and lasting source of development. However it is not sufficient alone to fully nurture program participants. Only programs that are built with the 70-20-10 
rule in mind can address different ways of learning and knowledge retention in a systematic and complete manner.

All best-in-class high potential leadership development programs leverage the following best practices:

Surround high potentials with quality people - potential grows when employees build interpersonal relationships with their coworkers who can help them do their jobs better and achieve their development goals. It fulfills aspiration and engagement elements of the high potential employee model. Building relationships with senior leaders by exposure to them during the development programs or special assignments will ultimately increase their commitment to the organization.

Build organizational commitment to high potentials development - require managers and leaders to actively coach, mentor, and provide formal high potential training. While pairing high potentials with mentors or coaches indicates organizational commitment, these relationships are more powerful when mentors help high potentials develop their network, improve job performance, and provide visibility into organizational strategy. When executive leaders display a commitment to employee development, potential can increase by as much as $29 \%$, Riddle (2012, p.2).

Challenge high potentials by giving them highly visible, on-the-job opportunities in order to push them to make risky decisions, learn new skills, and interact with different stakeholders. Most on-the-job experiences fall short of building employee potential. The most effective on-the-job development challenges high potentials with unfamiliar situations. When they adapt to changing circumstances and creatively solve problems, employee potential can improve by up to $15 \%$, Riddle (2012, p. 2).

The two examples below show how two well-known organizations, famous for their leadership development excellence, elevate their global leadership development practices.

Molson Coors: This Denver-based firm may be best known in the U.S. for its images of Rocky Mountain cold beer but Molson Coors also has breweries and brands in China, India, Ukraine, Czech Republic, Romania and other countries, complementing its markets in the U.S., Canada and the UK. Molson Coors' typical global leadership development program brings together approximately 20 participants in four one-week sessions over the course of a year. In 2013, the program included a kick-off week in Denver, a second week in Canada, a third week in an international market, and a fourth week in Central Europe. Each week includes a market tour, providing participants a first-hand look at distributors, breweries, grocery stores and restaurants to see how their products are sold globally. 
FedEx (Federal Express): has been in business for forty years and employs more than 160,000 team members servicing customers worldwide, yet the company doesn't lose sight of one significant key to its success: the vast majority of its frontline managers are promoted from within. To be successful, FedEx had to develop a robust leadership development process capable of preparing its workforce for the challenges of global frontline management. The organization services customers in 220 countries/territories, and a whopping $82 \%$ of FedEx frontline managers come from the ranks.

Clearly defined success outcomes for high potentials programs by determination of what organization wants to accomplish by the program. Key questions that needs to be answered should include:

- How will success be demonstrated within the organization?

- What kind of measurement tools will be used to show effectiveness?

- How will be correlation to the performance improvement shown?

Several tools are available:

a. Promotions tracking

b. Fulfillment of critical roles within organization

c. Retention

d. Performance ratings

e. Pre and post-program 360 assessments

Make the program as applicable as possible - making sure that the program is applicable to organizational problems or challenges helps to justify high potentials' time away from work while being trained. Making the program applicable and experiential allows participants to directly transfer the knowledge gained during the program to real life problems and current business challenges. Leveraging technology like connecting with leaders globally through videoconferencing or virtual meetings helps drive connectivity and communication across the silos. Action learning should concentrate on future challenges of the organization and should be used as tool to build organization strategy.

Balance organizational and personal goals - successful high-potential leadership initiative is a partnership between organization and its talented employees. Focusing only on the company needs and not meeting personal goals of best talent may fail to fill in the gap and provide whole developmental perspective. Providing structure for determining high potentials' needs and wants, and then following through on connecting what organization will need from them with targeted development opportunities is extremely important. Building strong development plan that is aligned with organizational as well as personal needs provides additional alignment within talent management development strategy. 
High potential program should be part of the development strategy - in order for organization to have an alignment in performance and development, high potential program should be part of a broader developmental strategy of the organization. The language, ideas as well as knowledge shared and taught during the leadership development program need to be delivered and disseminated to other levels of employees. Each high potential employee entering the program needs to have future career path mapped out with strategy and business challenges in mind. Otherwise, graduates may choose to satisfy newly built expectations with either other departments or different employers.

\section{CONCLUSION}

High potential employees form a talent pool that is critical to both succession planning and seizing new business opportunities. Only development programs that are rooted in current business strategy, founded on organization's culture, and providing a mix of structured learning as well as experiential activities, can deliver right people for right challenges.

\section{References:}

CEB Corporate Leadership Council's HIPO Program Operations and Outcomes Survey (2012); www.clc.exectiveboard.com

Fernández-Aráoz, C., Groysberg, B., and Nitin, N. (2011) How to hang on to your high potentials. Harvard Business Review, vol. 89 (10), p. 75-83

Ready, D., Conger, J., Hill, L., and Stecker, E. (2010) The anatomy of a high potential. Business Strategy Review, 21 (3), p. 52-55

AonHewitt, Building the Right High Potential Pool - How Organizations Define, Assess, and Calibrate Their Critical Talent, (January 2013) - Consulting Performance, Rewards and Talent, p. 4

Campbell, M. and Smith R. High-Potential Talent - A View from Inside the Leadership Pipeline, (2011), p. 6

O'Leonard, K. (2012) Investing in the Future: High Potentials, (September 2012), p. 12

Riddle, D. (2012) Your High-Potential Program Could Ruin Your Business, Harvard Business Review Blog, p. 2

Readings

Development First: Strategies for Self-Development by David B. Peterson and Mary Dee Hicks

Leader As Coach: Strategies for Coaching \& Developing Others by David B. Peterson Individual Development Planning: A Self-Development and Management Tool by Robert W Eichinger and Michael M Lombardo 
The CCL Handbook of Coaching: A Guide for the Leader Coach (J-B CCL (Center for Creative Leadership) by Sharon Ting and Peter Scisco

Career Distinction: Stand Out by Building Your Brand by William Arruda and Kirsten Dixson

What Color Is Your Parachute Workbook: How to Create a Picture of Your Ideal Job or Next Career by Richard Nelson Bolles

Personal Development for Smart People: by Steve Pavlina

StrengthsFinder 2.0 by Tom Rath 